\title{
Levobunolol and metipranolol: comparative ocular hypotensive efficacy, safety, and comfort
}

\author{
G K KRIEGLSTEIN,' G D NOVACK, ${ }^{23}$ E VOEPEL,${ }^{+} \mathrm{G}$ SCHWARZBACH, ${ }^{4}$ \\ U LANGE, ${ }^{+} \mathrm{K}$ P SCHUNCK, ${ }^{+} \mathrm{J} \mathrm{C} \mathrm{LUE}^{3}$ aNd E P GLAVINOS ${ }^{3}$
}

From the 'Department of Ophthalmology, University of Würzburg, $F R G,{ }^{2}$ University of California, Irvine, USA, ${ }^{3}$ Allergan Pharmaceuticals, Irvine, California, USA, and ${ }^{4} O p h$ thalmologists, F R G

SUMmaRY Topical levobunolol $0.5 \%$ was compared with topical metipranolol $0.6 \%$ for efficacy, safety, and comfort in 46 patients with open angle glaucoma or ocular hypertension. The study was of parallel design, randomised, double-masked, and of three months' duration. After a washout interval the study medications were instilled twice daily in both eyes. The overall mean decrease in intraocular pressure (IOP) was approximately $7 \mathrm{mmHg}$ in both groups. More than $90 \%$ of patients in both groups successfully completed the study. Both agents caused slight decreases in heart rate and blood pressure. More complaints of burning and stinging were reported in the metipranolol group than in the levobunolol group. This three-month, 46-patient study showed levobunolol $0.5 \%$ and metipranolol $0 \cdot 6 \%$ to be similarly effective ocular hypotensive agents.

Instilled topically into the eye, levobunolol elicits a profound, dose-related decrease in IOP in patients with ocular hypertension and glaucoma. ${ }^{12}$ In a twoyear, multicentre, double-masked study in 390 patients, twice daily levobunolol was found to be effective, relatively safe, and comfortable for the treatment of raised IOP. ${ }^{3}$

Metipranolol and levobunolol are non-cardioselective beta-adrenoceptor antagonists. Topically instilled metipranolol has been reported to be similar in efficacy to timolol in lowering intraocular pressure..$^{+5}$ Metipranolol has been reported to elicit ocular discomfort on instillation in some patients. ${ }^{6-8}$

Both levobunolol and metipranolol are approved for use as topical ocular hypotensive agents in Germany as well as several other countries. The objective of this study was to compare the ocular hypotensive efficacy, safety, and comfort of levobunolol $0.5 \%$ and metipranolol $0.6 \%$, administered twice daily, in patients with open angle glaucoma, ocular hypertension, or secondary glaucoma.

\section{Material and methods}

This study was a double-masked, parallel, randomised clinical trial of three months' duration. To be

Correspondence to Gary D Novack, PhD, Allergan Pharmaceuticals, 2525 Dupont Drive, Irvine, CA 92715, USA. included in the study patients had to have chronic open angle glaucoma, secondary glaucoma, or ocular hypertension.

Excluded from the study were patients with known cardiac or pulmonary conditions which would contraindicate the use of beta blockers. Concomitant oral antihypertensive medication was allowed if it was essential for the patient's health and remained constant throughout the study period. Before entering the trial all patients signed consent forms that described its design, purpose, and potential risks. Patients using ocular hypotensive medication were required to undergo a washout interval of two weeks or more for beta blockers, adrenalines, or clonidine, and four days or more for muscarinic agonists. After the washout the patients were required to have an intraocular pressure (IOP) of $22 \mathrm{mmHg}$ or greater in each eye. All patients received the study medication in both eyes.

After the baseline examination a drop of unlabelled study medication $(0.5 \%$ levobunolol or $0.6 \%$ metipranolol) was instilled into each of the patients' eyes. The patients were instructed to continue instillation of the study medication twice daily ( $7 \mathrm{am}$ to $8.30 \mathrm{am}$ and $9.30 \mathrm{pm}$ to $11 \mathrm{pm}$ ) for a three-month period. On follow-up examination days the morning medication was instilled after the examinations had been performed. Patients were removed from the 
trial either for adverse reaction to the study medication or for inadequate control of IOP, defined as unacceptably high intraocular pressures $(22 \mathrm{mmHg}$ or greater) in either eye on two consecutive morning visits 24 to 48 hours apart.

Follow-up examinations were scheduled at weeks $1,2,4,8$, and 12 . At each examination the presence of subjective complaints, such as burning from the drops, was carefully noted.

In all statistical analyses a $p$ value equal to or less than 0.05 was considered statistically significant. Right and left eye IOP values were averaged for analysis. Changes from baseline in IOP were calculated for each follow-up visit, and overall mean changes were calculated for the three-month study period. An analysis of variance was used for comparisons of mean IOP, heart rate, and blood pressure at baseline and mean changes from baseline among the treatment groups at each follow-up visit. An analysis of variance for repeated-measures designs ${ }^{9}$ was used to compare overall mean IOP changes (averaged over all study visits). Within-group changes were analysed by a paired $t$ test, subjective complaints with a $\chi^{2}$ test, and mean age by analysis of variance.

\section{Results}

Data for 46 patients with ocular hypertension or chronic open angle glaucoma were included in the analysis. Twenty-five patients were treated with $0.6 \%$ metipranolol, and 21 patients were treated with $0.5 \%$ levobunolol. Details of demographic and

Table 1 Demography: age, race, sex, iris colour, and diagnosis

\begin{tabular}{lll}
\hline & Metipranolol $0 \cdot 6 \%$ & Levobunolol $0 \cdot 5 \%$ \\
\hline Age & 25 & 21 \\
$\mathrm{n}$ & $59 \cdot 8 \pm 10 \cdot 4$ & $60 \cdot 5 \pm 13 \cdot 5$ \\
Mean $\pm \mathrm{SD}$ & $40-77$ & $20-80$ \\
Minimum & & \\
Race & 25 & 21 \\
White & 0 & 0 \\
Non-white & & \\
Sex & 10 & 10 \\
Male & 15 & 11 \\
Female & & \\
Iris colour & 15 & 7 \\
Blue & 3 & 2 \\
Green & 6 & 7 \\
Brown & 1 & 5 \\
Grey & & \\
Diagnosis & 13 & 11 \\
Ocular hypertension & 12 & 9 \\
Open-angle glaucoma & & \\
Ocular hypertension and & & \\
$\quad$ open angle glaucoma & 0 & \\
\hline
\end{tabular}

No significant between-group differences were noted.

*Ocular hypertension in one eye and glaucoma in the fellow eye.
Table 2 Intraocular pressure $(\mathrm{mmHg})$ : changes from baseline

\begin{tabular}{|c|c|c|c|c|c|c|}
\hline \multirow{3}{*}{$\begin{array}{l}\text { Week } 0 \\
\text { (baseline) }\end{array}$} & \multicolumn{3}{|c|}{ Metipranolol $0 \cdot 6 \%$} & \multicolumn{3}{|c|}{ Levobunolol $0 \cdot 5 \%$} \\
\hline & $n$ & Mean & $S D$ & $n$ & Mean & $S D$ \\
\hline & 25 & $26 \cdot 0$ & $3 \cdot 6$ & 21 & $25 \cdot 0$ & $2 \cdot 2$ \\
\hline 1 & 16 & $-7 \cdot 6$ & $5 \cdot 4$ & 14 & -6.9 & $2 \cdot 2$ \\
\hline 2 & 18 & $-7 \cdot 8$ & $4 \cdot 1$ & 14 & $-7 \cdot 6$ & $4 \cdot 4$ \\
\hline 4 & 13 & $-9 \cdot 2$ & $4 \cdot 2$ & 12 & $-6 \cdot 7$ & $2 \cdot 3$ \\
\hline 8 & 23 & $-7 \cdot 1$ & $4 \cdot 6$ & 15 & $-7 \cdot 1$ & $3 \cdot 0$ \\
\hline 12 & 23 & $-6 \cdot 9$ & $3 \cdot 8$ & 19 & $-6 \cdot 7$ & $2 \cdot 6$ \\
\hline \multicolumn{2}{|c|}{$\begin{array}{l}\text { Overall mean } \\
\text { change }\end{array}$} & $-7 \cdot 4$ & & & $-7 \cdot 2$ & \\
\hline
\end{tabular}

At each visit in both groups there were significant decreases from baseline in mean IOP.

No significant between-group changes were noted at any visit or for overall mean change.

glaucoma diagnosis data are shown in Table 1.

Of the 46 patients 43 successfully completed the three-month study. One metipranolol patient was removed from the trial for inadequate control of IOP and one levobunolol patient for reasons unrelated to the study. One levobunolol patient experienced shortness of breath and cramping of the chest while receiving the study medication. The patient discontinued the medication on her own and returned to her prestudy medication without sequelae.

An additional nine patients, not included in the analysis (six in the levobunolol group and three in the metipranolol group) participated in the study, though the baseline IOPs were less than $22 \mathrm{mmHg}$, in violation of the protocol entry criteria.

As shown in Table 2 and Fig. 1, the mean IOP at baseline was similar in both treatment groups. At follow-up visits the mean changes in IOP ranged from 6.7 to $7.6 \mathrm{mmHg}$ in the levobunolol $0.5 \%$ treatment group and from 6.9 to $9.2 \mathrm{mmHg}$ in the metipranolol $0.6 \%$ treatment group. At each visit in both groups the IOP was significantly reduced from the baseline. Analysis of overall mean changes in IOP indicated

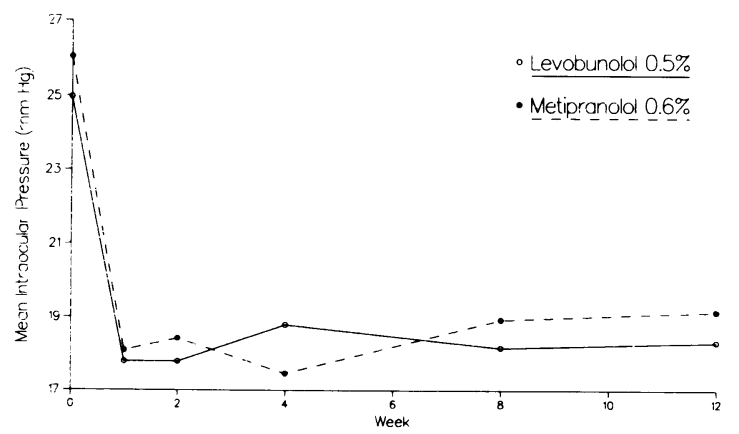

Fig. 1 Mean intraocular pressure. 
Table 3 Heart rate (bpm): mean changes from baseline

\begin{tabular}{|c|c|c|c|c|c|c|}
\hline \multirow{2}{*}{$\begin{array}{l}\text { Week O } \\
\text { (baseline) }\end{array}$} & \multicolumn{3}{|c|}{ Metipranolol $0 \cdot 6 \%$} & \multicolumn{3}{|c|}{ Levobunolol $0.5 \%$} \\
\hline & $n$ & Mean & $S D$ & $n$ & Mean & $S D$ \\
\hline & 25 & $74 \cdot 3$ & 7.9 & $20^{*}$ & $75 \cdot 1$ & $10 \cdot 3$ \\
\hline 1 & 16 & -0.5 & $7 \cdot 4$ & 14 & $-0 \cdot 8$ & $8 \cdot 4$ \\
\hline 2 & 18 & 0.9 & $10 \cdot 0$ & 14 & $-2 \cdot 0$ & $8 \cdot 1$ \\
\hline 4 & 13 & 0.2 & $7 \cdot 8$ & 12 & $-4.5 \dagger$ & $6 \cdot 0$ \\
\hline 8 & 23 & $0 \cdot 3$ & $7 \cdot 1$ & 15 & $-6.9+$ & $9 \cdot 5$ \\
\hline 12 & 23 & $-1 \cdot 2$ & $9 \cdot 6$ & 18 & $-4.8 \dagger$ & $7 \cdot 1$ \\
\hline $\begin{array}{l}\text { Overall mear } \\
\text { change }\end{array}$ & & -0.4 & & & $-3 \cdot 8$ & \\
\hline
\end{tabular}

There were significant between-group differences at Wecks 4 and 8 . There were no significant differences between the groups with respect to overall mean change.

${ }^{*}$ Heart rate at baseline was not reported for one subject.

†Significant within-group changes.

decreases of $7.2 \mathrm{mmHg}$ in the levobunolol treatment group and $7.4 \mathrm{mmHg}$ in the metipranolol treatment group. There was no significant difference in mean change in IOP between treatment groups at any visit, or in the overall mean changes. Statistical calculations indicated that the power to detect a $2 \mathrm{mmHg}$ difference between the two treatment groups was $57 \%$.

One metripranolol patient was found to have a slight increase of blind spot in one eye, as determined by visual field examination.

Hyperaemia of the lid and/or conjunctivia was observed in four levobunolol treated patients and six metipranolol treated patients. This was mild and not sufficient to stop beta blocker therapy.

The mean heart rate is shown in Table 3. At three visits statistically significant within-group decreases were seen in the levobunolol group. At two of these visits the decreases in the levobunolol group differed significantly from those in the metipranolol group. But these changes were of limited clinical significance. In addition, the overall mean changes in both groups were less than four beats per minute and not statistic-

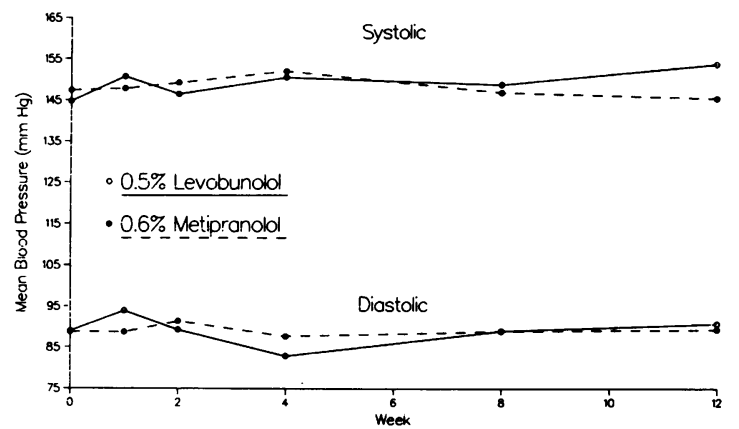

Fig. 2 Mean systolic and diastolic blood pressure.

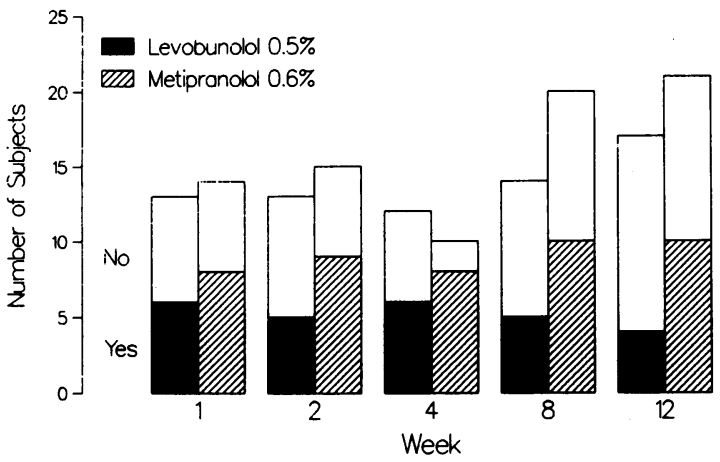

Fig. 3 Frequency of stinging or burning.

ally or clinically significantly different from each other. There were few changes of note in mean systolic and diastolic blood pressure in either treatment group (Fig. 2).

The incidence of stinging or burning is shown in Fig. 3. At each visit eight to $10(48 \%-80 \%)$ metipranolol treated patients reported stinging or burning, in contrast to four to six $(38 \%-56 \%)$ of the levobunolol treated patients. This difference was not statistically significant. No other patients' complaints were noted.

\section{Discussion}

The objective of this study was to evacuate the efficacy and safety of two $\beta_{1}$ and $\beta_{2}$-adrenoceptor antagonists, levobunolol and metipranolol, for the treatment of raised intraocular pressure. We found both levobunolol and metipranolol to be effective in lowering intraocular pressure an overall average of 7 to $7.5 \mathrm{mmHg}$, which is similar to previous reports for both drugs. ${ }^{378}$ However, one must be aware that the power of this study to detect a $2 \mathrm{mmHg}$ difference was only $57 \%$. Thus there was a $43 \%$ chance that there could have been a $2 \mathrm{mmHg}$ difference which was not detected by this study due to sampling variability.

As in previous reports ${ }^{7 x}$ metipranolol was found to cause burning and stinging. In the present study reports of burning and stinging were more frequent in metipranolol treated than in levobunolol treated patients. This difference was not statistically significant. However, the data from the both the present study and a previous comparison of metipranolol and levobunolol ${ }^{6}$ suggest that metipranolol may be less comfortable than levobunolol in glaucoma patients.

Decreases in heart rate and blood pressure, as observed in this study, have previously been reported for both levobunolol and metipranolol ${ }^{378}$ and are expected from topical therapy with a beta blocker.

The one apparently drug-related adverse experi- 
ence in the study was a pulmonary reaction in the levobunolol treatment group. While this 72-year-old patient had no history of pulmonary disease, it is possible that he had occult pulmonary disease which was exacerbated by the beta blocker treatment. Clearly all topical beta blockers may induce a pulmonary reaction in sensitive patients..$^{10-12}$

In the present three-month study levobunolol and metipranolol were found to be similar in efficacy. However, as glaucoma is a long-term disease, additional studies will be required to determine the comparative efficacy of these agents in long-term use.

The authors acknowledge the technical assistance of Cathy Bruns, BA.

\section{References}

1 Partamian LG, Kass MA, Gordon M. A dose-response study of the effect of levobunolol on ocular hypertension. Am J Ophthalmol 1983; 95: 229-32.

2 Duzman E, Ober M, Scharrer A, Leopold IH. A clinical evaluation of the effects of topically applied levobunolol and timolol on increased intraocular pressure. Am J Ophthalmol 1982; 94: 318-22.
3 Levobunolol Study Group. Levobunolol: a beta-adrenoceptor antagonist effective in the long-term treatment of glaucoma. Ophthalmology (Rochester) 1985; 92: 1271-6.

4 Merte H-J, ed. Metipranolol: pharmacology of beta-blocking agents and use of metipranolol in ophthalmology. Vienna, Ncw York: Springer, 1984.

5 Mills KB, Wright G. A blind randomised cross-over trial comparing metipranolol $0.3 \%$ with timolol $0.25 \%$ in open-angle glaucoma: a pilot study. Br J Ophthalmol 1986; 70: 39-42.

6 Ober M, Scharrer A, Novack GD, Lue JC. Die lokale subjektive Verträglichkeit von Levobunolol und Metipranolol in einer Doppelblind-Vergleichsstudie bei Patienten mit erhohtem Intraokularem Druck. Ophthalmologica 1986; 192:159-64.

7 Kruse W. Metipranolol-ein neuer beta Rezeptorenblocker. Klin Monatsbl Augenheilkd 1983; 182: 582-4.

8 Mertz M. Results of a 6 weeks' multicenter double-blind trial: metipranolol vs. timolol, in: Merte H-J, ed. Metipranolol: pharmacology of beta-blocking agents and use of metipranolol in ophthalmology. Vienna, New York: Springer, 1984: 93-105.

9 Winer BJ. Statistical principles in experimental design. New York: McGraw-Hill, 1971: 518-39.

10 Schoene R, Abuan T, Ward RL, Beasley H. Effects of topical betaxolol, timolol and placebo on pulmonary function in asthmatic bronchitis. Am J Ophthalmol 1984; 97: 86-92.

11 Van Buskirk EM, Fraunfelder FT. Ocular beta-blockers and systemic effects. Am J Ophthalmol 1984; 98: 623-4.

12 Spiritus EM, Casciari R. Letter to the editor: Am J Ophthalmol 1985; 100: 492-3.

Accepted for publication 25 June 1986. 